\title{
Analisis Kinerja Keuangan UMKM Sepatu dan Sandal di Desa Sindangsari Kecamatan Pabuaran Kabupaten Serang
}

\author{
Adih Supriadi dan Fiesty Utami \\ Fakultas Ekonomi dan Bisnis, Universitas Sultan Ageng Tirtayasa \\ Email korespondensi: adihs84@untirta.ac.id
}

\begin{abstract}
ABSTRAK
Analisis rasio dilakukan untuk menilai kondisi keuangan suatu organisasi. Tujuan penelitian ini ialah untuk melihat kondisi keuangan di UMKM Sepatu dan Sandal di Desa Sindangsari Kecamatan Pabuaran Kabupaten Serang ditinjau berdasarkan analisa rasio keuangan dengan metode analisis deskriptif. Kinerja keuangan UMKM Sepatu dan Sandal di Desa Sindangsari berdasarkan analisa rasio likuiditas selama periode tahun 2018 - 2020 terus mengalami penurunan yang artinya kemampuan perusahaan guna mencukupi kewajiban jangka pendeknya semakin menurun. Begitu juga berdasarkan rasio profitabilitas terus mengalami penurunan kinerja. Sedangkan berdasarkan rasio leverage periode tahun 2018-2020 nilainya sangat tinggi, padahal semakin kecil rasio leverage ini, tentunya akan semakin baik karena semakin kecil resiko yang dimiliki. Di sisi lain, berdasarkan rasio aktivitas perusahaan dalam mengelola aktivanya, perusahaan ini kurang efektif karena nilai yang didapat sangat kecil / rendah.
\end{abstract}

Kata kunci : Keuangan, Rasio, UMKM

\section{PENDAHULUAN}

Pertumbuhan jumlah Usaha Mikro Kecil dan Menengah terus berkembang. Berdasarkan data yang disajikan dari Kementerian Koperasi dan Usaha Kecil Menengah, ada kurang lebih 60 juta pelaku bisnis UMKM yang tersebar di Indonesia. UMKM dalam perspektif pajak adalah pengusaha yang memiliki omset per tahunnya di bawah Rp 4,8 Miliar. UMKM ini berperan menyerap pekerja Indonesia sekitar 97\% dari keseluruhan pekerja nasional, dan berkontribusi sekitar 60\% pada total PDB. Ketika masyarakat turut serta dalam UMKM, berarti masyarakat tersebut telah turut berperan penting dalam pembangunan nasional.

Akuntansi atau yang dikenal juga sebagai pembukuan ialah merupakan substansi yang sangat penting bagi perusahaan. Akuntansi sendiri adalah suatu seni pencatatan, peringkasan, penganalisisan, serta pelaporan berbagai informasi keuangan dari segala kegiatan perusahaan. Transaksi yang dicatat dalam sebuah pembukuan meliputi: penjualan, aset, biaya, hutang, dan modal. Dengan pembukuan, transaksi sekecil apapun akan diperhitungkan, sehingga setiap pemasukan dan pengeluaran bisa diketahui dengan jelas. Alhasil, pebisnis mampu membuat keputusan dengan tepat berdasarkan informasi yang ada. Dengan naiknya skala usaha, dibutuhkan juga tambahan pendanaan. Dengan catatan keuangan yang lengkap dan laporan yang jelas, akan lebih mudah dalam meyakinkan calon investor.

Pembukuan ialah sebagai media untuk pencatatan setiap transaksi yang terjadi dalam perusahaan (Mutiara, N. A., Wijayangka, C., \& Kartawinata, 2021). Kita dapat mengetahui berapa transaksi yang terjadi, jumlah uang yang didapat, dan berapa pengeluaran yang telah dikeluarkan. Sehingga, jalur keuangan akan terekam yang kemudian dapat mempermudah pemilik perusahaan dan stakeholder dalam mendapatkan gambaran profitabilitas perusahaan, baik itu laba maupun rugi.

Hasil akhir pembukuan ialah laporan keuangan. Laporan keuangan menghasilkan informasi pendapatan, biaya, laba, rugi, harta, hutang, dan posisi akumulasi modal perusahaan. 
Dengan pencatatan dan pembukuan yang baik, pengusaha dapat mengetahui berapa banyak modal yang dia keluarkan untuk mendapatkan barang dagangan sehingga dapat memeprhitungkan harga jual yang wajar. Biaya operasional yang harus diefisienkan, berapa dan kapan utang jatuh tempo, kapan piutang akan dibayar oleh pelanggan, dan lainnya.

Dengan adanya pembukuan yang jelas, investor dan calon investor dapat melihat tingkat keuntungan, dan memutuskan apakah akan menambahkan modal atau tidak (Adih Supriadi, 2020). Bank / kreditur; menilai laporan keuangan history keuangan bisnis untuk menilai apakah pinjaman dapat dikembalikan dalam jangka waktu yang disepakati. ichepi

Ada sepuluh prinsip di dalam akuntansi, namun ada lima prinsip penting yang perlu diterapkan dalam UMKM. Prinsip-prinsip tersebut antara lain entitas ekonomi (pencatatan hanya dilakukan untuk satu entitas ekonomi saja), konsistensi, dicatat dalam satuan moneter (rupiah untuk uang, kilogram untuk berat), full disclosure (semua transaksi harus dicatat dengan lengkap), dan berdasarkan periode pencatatan (pencatatan dibatasi ruang waktunya). Standar akuntansi yang digunakan oleh UMKM ialah SAK ETAP.

Kinerja keuangan akan dikatakan baik jika dapat meningkatkan usaha. Perkembangan dan pertumbuhan usaha membutuhkan elemen-elemen yang saling mendukung antara satu sama lain, yang mana kinerja keuangan yang meningkat merupakan usaha dalam memperbaiki keuangan Usaha Kecil dan Menengah (Ismanto, 2016). Perusahaan dapat melakukan analisis rasio, yang mana analisis rasio ini berguna untuk mengukur kinerja dari keuangan perusahaan (A. Supriadi, 2021). Hubungan antara elemen dalam laporan keuangan dapat dijelaskan dengan adanya alat analisis berupa analisis rasio keuangan.

Pengukuran atau analisis kinerja keuangan telah dimanfaatkan oleh peneliti-peneliti yang sebelumnya, diantaranya Seftianne, \& Handayani, (2011) yang menemukan bahwa kinerja PT. Ricky Putra Globalindo Tbk merupakan perusahaan industri tekstil yang berkinerja keuangan paling baik di tahun 2006, sedangkan PT. Polychem Indonesia Tbk merupakan perusahaan industry tekstil yang berkinerja keuangan yang paling baik di tahun 2007 dan 2008.

Penelitian Aut (2020) yang meneliti tentang UMKM Antik Gorden, menemukan bahwa hasil penilaian rasio keuangan Usaha Mikro Kecil dan Menengah Antik Gorden menunjukkan efisiensi yang dapat dikatakan baik. Adapun pernyataan akan hal ini sangat terlihat dari rasio solvabilitas dan profitabilitas. Di lain sisi, perusahaan memiliki rasio likuiditas yang kurang efisien. Hal ini diakibatkan perusahaan yang tidak mengambil pinjaman hutang yang dirasakan oleh perusahaan memiliki risiko lebih. Penelitian lain, yaitu penelitian Lia (2015) menunjukkan bahwa tingkat likuiditas UKM Ramayana Agro Mandiri sangatlah besar yang mana bisa disebut over liquidity. Resiko UKM Ramayana Agro Mandiri tersebut sangat rendah, karena tingkat leverage UKM tersebut sangat kecil. Namun, dikarenakan adanya penurunan kondisi perusahaan dalam dua tahun terakhir, maka tingkat profitabilitas dan aktivitas perusahaan UKM ini dalam kondisi yang kurang baik.

Penelitian tentang kinerja keuangan terdahulu juga pernah dilakukan kepada UMKM, yaitu antara lain penelitian Hamidah M. (2019) menemukan bahwa proporsi aktiva lancar lebih tinggi dibanding utang yang dimilikinya, dan adanya penurunan kinerja UMKM Japasrah dalam memperoleh laba bersih. Penelitian Erakipia, A. F., \& Gamaliel (2018) yang meneliti Usaha Mikro Kecil dan Menengah Amungme dan Kamoro, menemukan bahwa rasio keuangan dari kedua UMKM tersebut yaitu UKM Amungme dan Kamoro tersebut tergolong baik, namun jika mereview dari seleuruh rasio, masih ada rasio yang harus diperbaiki oleh perusahaan ini.

Berdasarkan penjelasan di atas, penulisan ini memiliki tujuan untuk mengamati kinerja keuangan pada UMKM Sepatu dan Sandal di Desa Sindangsari Kecamatan Pabuaran Kabupaten Serang ditinjau dari analisis rasio keuangan. 


\section{KAJIAN PUSTAKA}

\section{Kinerja Keuangan}

Menurut Susianti (2018) kinerja keuangan adalah kemampuan kerja dibidang keuangan yang telah diraih perusahaan secara finansial serta tertuang di laporan keuangan perusahaan. Kinerja Keuangan menurut Fenty (2017) merupakan gambaran tentang suatu kondisi keuangan yang tercermin sebagai prestasi kerja pada periode tertentu dengan dianalisis menggunakan media analisis tertentu, serta indikator baik buruknya manajemen untuk pengambilan keputusan.

\section{Laporan Keuangan}

Menurut IAI dalam Kariyoto (2017) laporan keuangan yang sesuai Standard Akuntansi Keuangan (SAK) yakni laporan yang menggambarkan efek keuangan atas transaksi atau moment lainnya yang sudah digolongkan dalam barisan besar berdasarkan karakter ekonominya. Menurut Wastam Wahyu (2018) kaporan keuangan yakni informasi yang mendeskripsikan keadaan keuangan company, dimana informasi tersebut dapat dimanfaatkan untuk menilai kinerja keuangan company.

Informasi keuangan dari sebuah organisasi dibuat menjadi sebuah laporan yaitu laporan keuangan. Dokumen laporan keuangan dibuat oleh perusahaan sebagai sarana komunikasi terutama dalam hal keuangann kepada pihak internal dan eksternal. Laporan keuangan ini ialah output dari proses pembukuan ataupun siklus akuntansi. Pelaporan yang disusun untuk disajikan kepada para pembuat keputusan atas bisnis perusahaan, terutama pembuat keputusan dari luar perusahaan, kemudian mengenai posisi keuangan perusahaan dan kondisi keuangan perusahaan (Soemarsono, 2004).

Laporan keuangan terdiri atas Laporan Neraca yang disebut Balance Sheet, Laporan Laba Rugi atau Income Statement, Laporan Arus Kas atau disebut juga Cash Flow Statement, Laporan Perubahan modal (Capital Statement), serta Catatan atas Laporan Keuangan (CaLK).

\section{Analisa Laporan Keuangan}

Analisa dari pelaporan keuangan yakni proses pembedahan pelaporan keuangan, serta menelaah komponen- komponen tersebut untuk memberikan pemahaman mengenai kinerja manajemen yang baik (Hery, 2015).

Menurut Sofyan (2019) analisis laporan keuangan yakni suatu media dan teknik dari pelaporan keuangan yang digunakan untuk mengolah data guna menghasilkan perhitungan maupun kesimpulan yang memberikan manfaat pada analisis bisnis.

Tujuan utama pada analisa laporan keuangan yaitu selaku alat barometer yang digunakan dalam mengerjakan forecasting dan membuat proyeksi atas posisi keuangan pada masa depan, melakukan review atas posisi atau kondisi perusahaan pada waktu tertentu, masalah- masalah manajemen, kegiatan operasional, kegiatan keuangan perusahaan, beserta alat ukur dalam melakukan pengefisiensian di seluruh departemen dalam perusahaan (Erica, 2017).

\section{Analisa Rasio}

Analisa pelaporan keuangan dapat dilakukan dengan menggunakan analisa rasio. Analisis rasio ialah suatu angka yang telah memperlihatkan jalinan beberapa unsur laporan keuangan dan dijabarkan secara matematis sederhana. Ada beberapa cara mengukur performance keuangan perusahaan yang berdasar pada analisis rasio keuangan menurut Hantono (2018) yaitu:

\section{Rasio Likuiditas}

Rasio likuiidtas ialah untuk memperhitungkan kemampuan dari suatu perusahaan untuk melunasi atau melakukan pembayaran atas hutang - hutang jangka pendek perusahaan, mengukur angka keamanan kredit jangka pendek. Rasio likuiditas terdiri dari: 
1) Current Rasio

2) Quick Ratio

$$
\text { Current Rasio }=\frac{\text { Aktiva lancar }}{\text { Kewajiban lancar }}
$$

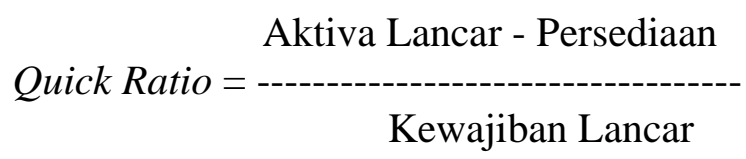

3) Cash Ratio

\section{Rasio Leverage (Leverage Ratios)}

$$
\begin{gathered}
\text { Kas + Efek } \\
\text { Kewajiban Lancar }
\end{gathered}
$$

Rasion ini melakukan pengukuran sampai seberapa jauhkah aset perusahaan ini dibiayai dengan adanya hutang. Jika perusahaan beroperasi sepenuhnya menggunakan modal sendiri maka leveragenya 0 . Rasio Leverage terdiri atas :

1) Total Debt To Total Asset Ratio

$$
\text { Debt Ratio = }=\frac{\text { Jumlah Hutang }}{\text { Jumlah Aktiva }} \text { x 100\% }
$$

2) Debt To Equity Ratio

$$
D E R=\frac{\text { Jumlah Hutang }}{\text { Modal Sendiri }}
$$

3) Time Interest Earned Ratio

$$
\text { TIER = ------------------------- }
$$

Rasio Aktivitas (Aktivity Ratios)

Rasio ini menilai besaran efektifitas company dalam menarik manfaat dari berbagai sumber dana yang dimilikinya. Semakin suatu perusahaan efektif dalam memanfaatkan dana perusahaan, tentunya akan semakin cepat pula perputaran dari masing-masing elemen aktiva. Ratio ini meliputi :

1) Perputaran Aktiva Tetap (Fixed Assets Turnover)

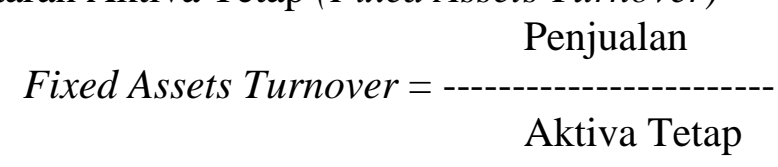

2) Perputaran Aktiva (Assets Turnover)

$$
\text { Perputaran aktiva }=\frac{\text { Penjualan }}{-------} \text { Total Aktiva }
$$


Ratio Keuntungan (Profitability Ratios)

Keuntungan yang didapat oleh perusahaan, dinilai dengan menggunakan rasio ini. Tentunya, semakin besar besaran tingkat profitabilitas, maka akan semakin baik pola manajemen dalam pengelolan company. Adapun yang termasuk dalam rasio ini adalah :

1) Profit Margin

$$
\text { Profit Margin = } \frac{\text { EBIT }}{\text { Penjualan }}
$$

2) Return On Asset (ROA)

$$
\text { ROA = } \frac{\text { EBIT }}{\text { Jumlah Aktiva }}
$$

3) Return On Equity (ROE)

$$
\text { ROE }=\frac{\text { EAT }}{\text { Modal Sendiri }}
$$

4) Return On Investmen (ROI)

$$
\mathrm{ROI}=\frac{\text { EAT }}{\text { Investasi }}
$$

\section{Usaha Mikro Kecil Menengah (UMKM)}

Micro, Small and Medium Enterprise (MSME) is a business able of giving broad economic services to the society and expanding employment (Supriadi, dkk. 2020). Berdasarkan UndangUndang Republik Indonesia Nomor 20 Tahun 2008 Tentang Usaha Mikro, Kecil, Dan Menengah (UMKM) pengertian dari Usaha Mikro, Kecil, dan Menengah ialah merupakan sebagai bisnis yang bisa dioperasikan oleh tidak hanya badan usaha yang masih berukuran kecil, namun juga individu dan rumah tangga. Pengklasifikasian UMKM ini lazimnya dilakukan dengan batasan banyaknya omzet dari perusahaan tersebut per tahun nya, banyaknya aset perusahaan, serta banyaknya karyawan perusahaan.

Usaha Mikro, Kecil, dan Menengah yang biasa juga disebut UMKM ini dikelompokkan berdasarkan kriteria hasil penjualan secara tahunan dan modal usahanya. Adapun kriteriaa UMKM menurut Peraturan Pemerintah No.7 Tahun 2021 Tentang Kemudahan, Pelindungan, Dan Pemberdayaan Koperasi Dan Usaha Mikro, Kecil, Dan Menengah adalah :

1. Modal usaha dari usaha mikro ialah maksimal satu miliar rupiah, dan ini terkecuali dengan tanah serta bangunan atas tempat usaha tersebut berada. Adapun hasil dari penjualan tahunan perusahaan dari usaha mikro ini maksimal sampai dengan dua miliar rupiah;

2. Modal usaha dari usaha kecil ialah di atas satu miliar rupiah dan maksimal ialah lima miliar rupiah. Jumlah tanah serta bangunan tempat usaha UMKM ini dijalankan dickecualikan dari jumlah modal usaha ini. Usaha Kecil mempunyai range hasil atas penjualan perusahaan tahunan yang mana lebih dari dua miliar rupiah hingga maksimal lima belas miliar rupiah; 
3. Modal usaha dari usaha menengah ialah lebih dari lima miliar rupiah dan maksimal ialah sepuluh rniliar rupiah. Jumlah ini terkecuali dengan tanah beserta bangunan tempat usaha perusahaan UMKM ini dijalankan. Bisnis Usaha Menengah memiliki hasil penjualan tahunan yaitu di atas lima belas miliar rupiah hingga lima puluh miliar rupiah.

\section{METODE PENELITIAN}

Penelitian ini melakukan perbandingan kinerja UMKM Sepatu dan Sandal di Desa Sindangsari Kecamatan Pabuaran Kabupaten Serang dari tahun 2018-2020 melalui penghitungan analisis rasio keuangan, yaitu berupa 4 rasio yakni rasio likuiditas, rasio solvabilitas, profitabilitas, serta rasio aktivitas. Adapun data yang dimanfaatkan oleh peneliti dalam penelitian kinerja keuangan ini adalah data kuantitatif. Penelitian ini memanfaatkan populasi yaitu laporan keuangan UMKM Sepatu dan Sandal tahun 2018, 2019, dan 2020. Time series analysis diperlukan dalam penelitian ini sebagai teknik analisis data untuk membandingkan berbagai rasio keuangan laporan keuangan pada suatu periode tertentu yaitu 2018, 2019, dan 2020.

\section{HASIL DAN PEMBAHASAN}

Berdasarkan hasil laporan keuangan UMKM Sepatu dan Sandal di Desa Sindangsari Kecamatan Pabuaran Kabupaten Serang untuk periode Tahun 2018-2020, dapat disajikan pelaporan keuangan tersebut yang berupa laporan laba rugi dan neraca:

Tabel 1. Laporan Laba Rugi

\begin{tabular}{|c|c|c|c|c|}
\hline No. & Uraian & 2018 & 2019 & 2020 \\
\hline 1 & Penjualan & 275.563 .000 & 270.000 .000 & 80.250 .000 \\
\hline 2 & HPP & 150.000 .000 & 155.000 .000 & 55.325 .000 \\
\hline & Laba Kotor & 125.563 .000 & 115.000 .000 & 24.925.000 \\
\hline 1 & Total Beban dan biaya & 76.485 .000 & 82.450 .000 & 17.500 .000 \\
\hline 2 & Pajak & - & - & - \\
\hline & Laba bersih & 49.075.000 & 32.550 .000 & 7.425.000 \\
\hline
\end{tabular}

Sumber: data keuangan UMKM Sepatu dan Sandal Sindangsari

Tabel 2. Laporan Posisi Keuangan / Neraca

\begin{tabular}{|c|c|c|c|c|c|c|c|c|c|}
\hline \multicolumn{5}{|c|}{ AKTIVA (000) } & \multicolumn{5}{|c|}{ PASSIVA (000) } \\
\hline No. & Uraian & 2018 & 2019 & 2020 & No & Uraian & 2018 & 2019 & 2020 \\
\hline I & Aktiva Lancar & 185.000 & 187.500 & 26.000 & III. & Kewajiban & 167.925 & 179.950 & 33.575 \\
\hline & Kas & 5.000 & 10.000 & 1.000 & & Kewajiban.Jk.Pendek & 67.925 & 79.950 & 13.575 \\
\hline & Bank & 25.000 & 27.500 & 10.000 & & Cicilan.Leasing & 5.925 & 5.950 & 3.575 \\
\hline & Persediaan & 155.000 & 150.000 & 15.000 & & Angsuran Mitra & 40.000 & 40.000 & 5.000 \\
\hline & & & & & & Angsuran Bank & 22.000 & 32.000 & 5.000 \\
\hline & & & & & & Kewajiban.Jk.Panjang & 100.000 & 100.000 & 20.000 \\
\hline & & & & & & Hutang Mitra & 60.000 & 70.000 & 15.000 \\
\hline & & & & & & Hutang bank & 40.000 & 30.000 & 5.000 \\
\hline II & Aktiva Tetap & 82.000 & 75.000 & 65.000 & IV. & Modal & 99.075 & 82.550 & $\mathbf{5 7 . 4 2 5}$ \\
\hline & Tanah\&Bangunan & 0 & 0 & 0 & & Modal Awal & 50.000 & 50.000 & 50.000 \\
\hline & Mesin\&Peralatan & 75.000 & 70.000 & 65.000 & & Laba Tahun berjalan & 49.075 & 32.550 & 7.425 \\
\hline & Inventaris & 7.000 & 5.000 & 5.000 & & & & & \\
\hline & Total Aktiva & 267.000 & 262.500 & 91.000 & & Total.Passiva & 267.000 & 262.500 & 91.000 \\
\hline
\end{tabular}

Sumber: data keuangan UMKM Sepatu dan Sandal Sindangsari

Berdasarkan laporan keuangan diatas, dapat dilakukan analisa laporan keuangan berdasarkan analisa rasio, yaitu rasio likuiditas, profitabilitas, aktivitas dan solvabilitas yang bertujuan untuk menilai kinerja perusahaan dalam bidang keuangan. Berikut hasil dan pembahasan 
analisa rasio keuangan pada UMKM Sepatu dan Sandal di Desa Sindangsari Kecamatan Pabuaran Kabupaten Serang :

Tabel 3. Analisis Rasio Likuiditas

\begin{tabular}{|l|c|c|c|}
\hline \multicolumn{1}{|c|}{ Ratio } & $\mathbf{2 0 1 8}$ & $\mathbf{2 0 1 9}$ & $\mathbf{2 0 2 0}$ \\
\hline Current Ratio & 2,72 & 2,35 & 1,9 \\
\hline Quick Ratio & 0,44 & 0,47 & 0,8 \\
\hline Cash Ratio & 0,07 & 0,13 & 0,07 \\
\hline
\end{tabular}

Sumber: data keuangan UMKM diolah

Rasio Likuiditas ialah suatu rasion untuk melakukan pengukuran atas kemampuan dari organisasi untuk melakukan pembayaran atas segala hutang jangka pendeknya. Kondisi likuiditas UMKM Sepatu dan Sandal di Desa Sindangsari selama 3 tahun terus mengalami penurunan yang artinya kemampuan perusahaan guna mencukupi kewajiban jangka pendeknya semakin menurun, yaitu pada periode tahun 2018 sebesar 2,72 periode tahun 2019 ialah sebesar 2,35 dan tahun 2020 ialah sebesar 1,9. Hal tersebut dapat diketahui berdasarkan atas besaran prosentase dari rasio tersebut. Berdasarkan perhitungan analisa rasio likuiditas, UMKM Sepatu dan Sandal di Desa Sindangsari selama periode 2018-2020 terus mengalami penurunan yang artinya kemampuan perusahaan guna mencukupi kewajiban jangka pendeknya semakin menurun.

Tabel 4. Analisis Rasio Profitabilitas

\begin{tabular}{|l|c|c|c|}
\hline \multicolumn{1}{|c|}{ Ratio } & $\mathbf{2 0 1 8}$ & $\mathbf{2 0 1 9}$ & $\mathbf{2 0 2 0}$ \\
\hline Net Profit Margin & $17,8 \%$ & $12,05 \%$ & $9,25 \%$ \\
\hline Return on Asset (ROA) & $18,38 \%$ & $12,4 \%$ & $8,15 \%$ \\
\hline Return on Equity (ROE) & $49,5 \%$ & $39,4 \%$ & $12,9 \%$ \\
\hline
\end{tabular}

Sumber: data keuanga UMKM Sepatu dan Sandal Sindangsari (diolah)

Rasio profitabilitas yang diseajikan dalam tabel 4 di atas terdiri dari net profit margin yang mana rasio ini dimanfaatkan untuk mengukur besar kemampuan dari suatu perusahaan untuk mendapat laba bersih dari hasil operasinya. Hasil dari analisa atas net profit margin memperlihatkan bahwa presentase pada tahun 2018 sebesar 17,8\% dan pada tahun 2019 sebesar $12,05 \%$, serta pada tahun 2020 sebesar 9,25\%. Kondisi tersebut merupakan hasil penjualan yang telah dihasilkan UMKM Sepatu dan Sandal di Desa Sindangsari. Berdasarkan data tersebut berarti perusahaan tersebut terus mengalami penurunan setiap tahunnya dalam menghasilkan laba.

Return on Asset (ROA) yaitu rasio untuk menakar kemampuan company dalam mendapatkan profit dengan semua asset yang dimiliki. Sama halnya dengan net profit margin, rasio ini pada UMKM Sepatu dan Sandal di Desa Sindangsari pada tahun 2018 sebesar 18,38\%, di tahun 2019 sebesar 12,4\% dan di tahun 2020 sebesar 8,15\%. Hal ini membuktikan bahwa kinerja perusahaan pada setiap tahunnya terus menurun kinerjanya dalam pemanfaatan asset untuk mendapatkan laba bersih.

Return on Equity (ROE) yaitu rasio untuk menakar kemampuan company dalam mendapatkan profit dengan modal sendiri yang dimiliki. Prosentase ROE pada tahun 2018 sebesar 49,5\%, tahun 2019 ialah sebesar 39,4\% dan sedangkan tahun 2020 ialah sebesar 12,9\%. Dalam hal ini, UMKM Sepatu dan Sandal di Desa Sindangsari mengalami penurunan kinerja selama periode 2018-2020 terkait dengan penggunaan ekuitas untuk memperoleh pendapatan bersih.

Dengan demikian berdasarkan analisa rasio profitabilitas, UMKM Sepatu dan Sandal di Desa Sindangsari mengalami penurunan kinerja selama periode 2018-2020 terkait dengan penggunaan ekuitas untuk memperoleh pendapatan bersih. 
Tabel 5. Analisis Rasio Leverage

\begin{tabular}{|l|c|c|c|}
\hline \multicolumn{1}{|c|}{ Ratio } & $\mathbf{2 0 1 8}$ & $\mathbf{2 0 1 9}$ & $\mathbf{2 0 2 0}$ \\
\hline Debt to Assets Ratio & $62,89 \%$ & $68,55 \%$ & $36,89 \%$ \\
\hline Debt to Equity Ratio & $169,49 \%$ & $217,99 \%$ & $58,46 \%$ \\
\hline
\end{tabular}

Sumber: data keuanga UMKM Sepatu dan Sandal Sindangsari (diolah)

Hasil dari tabel 5 di atas merupakan perhitungan analisa keuangan menggunakan rasio leverage yang berupa dua rasio yaitu debt to equity ratio serta debt to asset ratio. Debt to asset ratio (DAR) adalah perhitungan rasio dimana adanya pengukuran aktiva sebagai penjamin seluruh kewajiban yang telah dimiliki. DAR Pada tahun 2018 diperoleh sebesar 62,89\% serta untuk periode 2019 sebesar 68,55\% dan periode 2020 sebesar 36,89\%

Debt to Equity Ratio (DER) adalah perhitungan modal sendiri sejauh mana hal tersebut dapat menjamin kewajiban yang dimiliki. Hasil DER dari tabel 5 di atas pada tahun 2018 adalah sebesar 169,49\% serta untuk periode tahun 2019 sebesar 217,99 dan pada tahun 2020 sebesar $58,46 \%$. Semakin kecil rasio dari debt to equity ratio ini, maka tentunya akan semakin baik juga perusahaan tersebut karena semakin kecil resiko yang ditanggung ketika ada kemungkinan kegagalan yang terjadi pada company.

Tabel 6. Analisis Rasio Aktivitas

\begin{tabular}{|l|c|c|c|}
\hline \multicolumn{1}{|c|}{ Ratio } & $\mathbf{2 0 1 8}$ & $\mathbf{2 0 1 9}$ & $\mathbf{2 0 2 0}$ \\
\hline Inventory Turnover & 3,36 & 3,6 & 1,23 \\
\hline Total Asset Turnover & 1,03 & 1,02 & 0,88 \\
\hline Sumber & & \\
\hline
\end{tabular}

Sumber: data keuangan UMKM Sepatu dan Sandal Sindangsari (diolah)

Pada tabel 6 di atas mengukur kinerja menggunakan rasio aktivitas, yang terdiri dari Inventory Turnover yaitu kemampuan perusahaan dalam melakukan perputaran persediaan untuk dijual dan diadakan kembali dalam periode tertentu. Hasil dari analisa rasio di atas menunjukkan bahwa pada tahun 2018 sebesar 3,36 kali dan pada tahun 2019 sebesar 3,6 kali dan tahun 2020 sebanyak 1,23 kali. Berdasarkan data tersebut berarti kemampuan perusahaan dalam melakukan perputaran persediaan tahun 2018 sebesar 3,36 kali dan mengalami peningkatan sedikit pada tahu 2019 yaitu 3,6 kali namun pada tahun 2020 mengalami penurunan sangat drastis menjadi 1,23 kali.

Total asset turnover yaitu untuk mengukur kemampuan manajemen sebagai pengelolaan seluruh investasi (aktiva) untuk menghasilkan penjualan. Hasil analisa rasio pada tabel 6 yang tersaji di atas dapat diketahui bahwa perputaran asset pada tahun 2018 sebanyak 1,03 kali, tahun 2019 sebanyak 1,02 kali dan tahun 2020 sebanyak 0,88 kali. Berdasarkan hasil pada tabel 6 di atas, berarti perusahaan dalam mengelola aktivanya kurang efektif karena nilai yang didapat sangat kecil/rendah.

\section{KESIMPULAN}

Hasil dari analisis keuangan berdasar rasio keuangan di atas, dapat dilihat kesimpulan sebagai berikut :

1. Kinerja keuangan UMKM Sepatu dan Sandal di Desa Sindangsari berdasarkan analisa rasio likuiditas selama periode 2018-2020 terus mengalami penurunan yang artinya kemampuan perusahaan guna mencukupi kewajiban jangka pendeknya semakin menurun, yaitu Current ratio periode tahun 2018 ialah sebesar 2,72, tahun 2019 ialah sebesar 2,35 dan tahun 2020 ialah sebesar 1,9. Quick ratio tahun 2018 ialah sebesar 0,44 tahun 2019 ialah sebesar 0,47 dan tahun 2020 ialah sebesar 0,8. Sedangkan Cash Ratio tahun 2018 ialah sebesar 0,07 tahun 2019 ialah sebesar 0,13 dan 0,07 pada tahun 2020 . 
2. Kinerja keuangan UMKM Sepatu dan Sandal di Desa Sindangsari berdasarkan rasio profitabilitas terus mengalami penurunan kinerja selama periode 2018-2020 terkait dengan penggunaan ekuitas untuk memperoleh pendapatan bersih.

3. Kinerja keuangan UMKM Sepatu dan Sandal di Desa Sindangsari berdasarkan rasio leverage periode tahun 2018-2020 nilainya sangat tinggi, padahal semakin kecil rasio leverage ini, maka semakin baik karena semakin kecil resiko yang ditanggung ketika ada kemungkinan kegagalan yang terjadi pada perusahaan.

4. Kinerja keuangan UMKM Sepatu dan Sandal di Desa Sindangsari berdasarkan rasio aktivitas, inventory turnover bahwa di tahun 2018 sebesar 3,36 kali dan di tahun 2019 sebesar 3,6 kali dan tahun 2020 sebanyak 1,23 kali. Berdasarkan data tersebut berarti kemampuan perusahaan dalam melakukan perputaran persediaan tahun 2018 sebesar 3,36 kali dan mengalami peningkatan sedikit pada tahu 2019 yaitu 3,6 kali namun pada tahun 2020 mengalami penurunan sangat drastis menjadi 1,23 kali. Sedangkan Total asset turnover pada tahun 2018 sebanyak 1,03 kali, tahun 2019 sebanyak 1,02 kali dan tahun 2020 sebanyak 0,88 kali. Berdasarkan hasil pada tabel 6 di atas, berarti perusahaan dalam mengelola aktivanya kurang efektif karena nilai yang didapat sangat kecil/rendah.

\section{SARAN}

1. Untuk meningkatkan kinerja UMKM Sepatu dan Sandal di Desa Sindangsari melalui rasio likuiditas, maka semaksimal mungkin manajemen harus menambah pertumbuhan aktiva lancar dan mengurangi kewajiban perusahaan.

2. Untuk meningkatkan profitabilitas UMKM Sepatu dan Sandal di Desa Sindangsari, seharusnya dapat menggunakan aktiva lancar dan modal kerja secara efisien. Aktiva lancar yang terlalu tinggi mengakibatkan dana menganggur dan tidak produktif serta hal ini tidak baik untuk kinerja keuangan perusahaan. Maka pihak manajemen seharusnya melakukan pengontrolan operasional yang dapat meningkatkan efisiensi operasi perusahaan sehingga dapat meningkatkan laba perusahaan.

3. Untuk meningkatkan kinerja UMKM Sepatu dan Sandal di Desa Sindangsari melalui rasio solvabilitas, maka manajemen harus meningkatkan aktiva dan modal guna menjamin kewajiban yang dimiliki.

4. Untuk meningkatkan kinerja UMKM Sepatu dan Sandal di Desa Sindangsari melalui rasio aktivitas, maka manajemen harus meningkatkan perputaran persediaan, aktiva serta modal kerja perusahaan.

\section{DAFTAR PUSTAKA}

Aut, A. S. (2020). Analisis Laporan Keuangan Sebagai Dasar Penilaian Kinerja Keuangan Umkm Dengan Menggunakan Rasio Keuangan (Studi Kasus Pada Antik Gorden Pontianak). Jurnal Kajian Ilmiah Akuntansi Fakultas Ekonomi UNTAN (KIAFE), 10(3).

Erakipia, A. F., \& Gamaliel, H. (2018). Analisis laporan keuangan sebagai dasar penilaian kinerja keuangan pada UMKM Amungme dan Kamoro. Jurnal EMBA: Jurnal Riset Ekonomi, Manajemen, Bisnis Dan Akuntansi, 5(1).

Erica, D. (2017). Analisa Rasio Laporan Keuangan Untuk Menilai Kinerja Perusahaan PT Kino Indonesia Tbk. Jurnal Ecodemica, 2(1), 12-20.

Fenty, P. D. (2017). Pengaruh Kualitas Penerapan Good Corporate Governance Terhadap Financial Distress. Doctoral Dissertation.

Hamidah, M., dkk. (2019). Penggunaan Analisa Rasio Keuangan Guna Menilai Kinerja Keuangan Umkm Japasrah. Inovasi Manajemen Dan Kebijakan Publik, 2(2), 18-28.

Hantono. (2018). Akuntansi Keuangan Lanjutan. Deepublis.

Hery. (2015). Analisis Kinerja Manajemen. Gramedia Widiasarana Indonesia.

Ismanto, H. (2016). Analisis kinerja keuangan UMKM tenun ikat troso jepara. Jurnal Economia, 12(2), 159-166. 
Kariyoto, K. (2017). Persepsi Akuntansi Sektor Publik versus Akuntansi Pemerintahan. Jurnal Ilmiah Bisnis Dan Ekonomi Asia, 11(2), 18-27.

Lia, D. A. Z. (2015). Penilaian Kinerja Keuangan Pada Usaha Kecil dan Menengah (UKM) Berdasarkan Analisis Rasio Keuangan (Studi pada IRT Ramayana Agro Mandiri Kota Batu Tahun 2011-2014). Jurnal Administrasi Bisnis, 25(1).

Mutiara, N. A., Wijayangka, C., \& Kartawinata, B. R. (2021). Adopsi Media Sosial Terhadap Kinerja Umkm Di Kota Bandung. Jurnal Ilmiah MEA (Manajemen, Ekonomi, \& Akuntansi), 5(1), 1673-1684.

Peraturan Pemerintah No.7 tahun 2021 tentang Kemudahan, Pelindungan, dan Pemberdayaan Koperasi dan Usaha Mikro, Kecil, dan Menengah. (n.d.).

Seftianne, \& Handayani, R. (2011). Faktor-faktor yang mempengaruhi struktur modal pada perusahaan publik sektor manufaktur. Jurnal Bisnis dan Akuntansi. Jurnal Bisnis Dan Akuntansi, 13(1), 39-56. https://jurnaltsm.id/index.php/JBA/article/vie w/214

Soemarsono, S. R. (2004). Akuntansi Suatu Pengantar (5th ed.).

Sofyan, M. (2019). Rasio Keuangan Untuk Menilai Kinerja Keuangan. Akademika, 17(2), 115121.

Supriadi, A., Maria, V., \& Bahiroh, E. (2020). Hand Crafts Materials Of Clay (Study Of Household In Bumi Jaya Village Ciruas District Serang). Jurnal Manajemen Dan Bisnis, 9(2), 166-173.

Supriadi, A. (2021). Analysis of The Effects Debt Capital, Equity Capital on Residual Income and It Is Impacts on Amount Coperative Member. Jurnal Sains Sosio Humaniora, 5(1), 174-185.

Supriadi, Adih. (2020). Analisis Pengaruh Debt Capital Dan Equity Capital Terhadap Sisa Hasil Usaha (Shu) Koperasi.

EkoPreneur, 1(2), 131. https://doi.org/10.32493/ekop.v1i2.5143

Susianti, I. (2018). Analisis laporan keuangan untuk menilai kinerja keuangan pada PT. Gudang Garam Tbk. pada periode 2013-2015. Jurnal Simki-Economic, 2(02), 2599-0748.

Undang-Undang Republik Indonesia Nomor 20 Tahun 2008 tentang Usaha Mikro, Kecil, dan Menengah (UMKM). (n.d.).

Wastam Wahyu, H. (2018). Pengaruh Profitabilitas, Leverage Dan Pertumbuhan Penjualan Terhadap Penghindaran Pajak. Jurnal Riset Manajemen Bisnis (JRMB), 3(1), 19-26. 